\title{
Analysis of social responsibility of mining companies in the international market
}

\author{
Olena Kozyrieva ${ }^{1, *}$, Nataliia Tkalenko $^{2}$, Valentina Vyhovska $^{3}$, and Alina Pinchuk ${ }^{4}$ \\ ${ }^{1}$ National University of Pharmacy, Doctor of Economics, Professor, Head of the Department of \\ Management and Public Administration, 61057, 53 Pyshkinskaya street, Kharkiv, Ukraine \\ ${ }^{2}$ Chernihiv Polytechnic National University, Public Administration and Business Management \\ Department, 14035, Chernihiv, Shevchenko str.,95, Ukraine \\ ${ }^{3}$ Chernihiv Polytechnic National University, Doctor of Economics, Professor, Department of Finance, \\ Banking and Insurance, 14035, Chernihiv, Shevchenko str.,95, Ukraine \\ ${ }^{4}$ Chernihiv Polytechnic National University, Department of Finance, Banking and Insurance, 14035, \\ Chernihiv, Shevchenko str.,95, Ukraine
}

\begin{abstract}
The article proves that the implementation of the principles and use of the tools of corporate social responsibility can increase the reputation of the corporation and its activity in the world market. The purpose of the article is to substantiate and determine the role of corporate social responsibility of the mining and metals companies in ensuring and improving their reputation in the world market. The article substantiates that the low level of corporate governance practice and insufficient part of social contribution to the companies negatively affect formation of corporate social responsibility of the corporations. The article analyzes the indicators of Corporate sustainability and Transparency for 2018-2019 according to the professional rating of the largest Ukrainian mining and metals companies, based on leading international practices. The analysis of indicators made it possible to identify the proportional dependence of the reputation of the corporation on the measures of corporate social responsibility that the latter implements. It is determined on the basis of the study that corporate social responsibility is an effective tool to increase the competitiveness of mining and metals companies.
\end{abstract}

\section{Introduction}

Amidst the development of globalization processes, the primary objective of the leading mining companies is to maintain their position in the international market and increase competitiveness. In recent years, a powerful tool to improve the reputation in the global market for large corporations has been the formation of an effective strategy of corporate social responsibility (CSR), which aims to ensure economic sustainability, environmental security, social protection, human rights in the field of labor relations. A number of governments are implementing CSR ideas into regular business practice and creating favorable conditions for socially responsible behavior of national and foreign enterprises.

\footnotetext{
*Corresponding author: yakakos74@gmail.com
} 
The reason thereof is that the tools of corporate social responsibility have become an important component of each state's sustainable development strategy, which provides a number of benefits for its socio-economic development (investment attractiveness, economic competitiveness, environmental development, social capital growth, anticorruption), ensuring the prosperity of mining companies in the long run, attracting investment to achieve sustainable development through the introduction of the principles of social responsibility, which significantly affect the reputation of mining companies in the global market.

\section{Results and Discussion}

CSR Europe, Global Sustainable Investment Alliance, CSRHub, Youmatter, Fortune, Brand Finance, Newsweek, Customer guru, CSR Development Center analyze application of the principles of corporate social responsibility in the activities of corporations and trends in the company's reputation at the international level. The publications and reports highlight the principles, features of corporate social responsibility of corporations, assess the development of CSR and reputation rating, compare these practices with global trends. To determine the practical significance of implementing the principles of corporate social responsibility and its impact on the reputation of the corporation further refinement and development of the topic is required.

Corporate social responsibility implies a strategy to improve the reputation of the mining company and allows you to make business more innovative, increase sales. Focused on the economic interests, such companies achieve effective results by maintaining ethical standards, social and environmentally friendly attitude to the environment, the mutual coordination of the interests of key stakeholders [1].

In the context of national and international development, corporate social responsibility is becoming increasingly important for the formation of national and regional development programs.

CSRHub Corporation, which aims to facilitate access to information on sustainability and corporate social responsibility, evaluates performance of the corporations by 12 indicators, including society, government, environment, labor policy and others. The company's software processes data in a total score from 0 to 100 . The higher the overall score, the better.

In countries that are at a stage between an efficiency-based economy and an innovationdriven economy, corporate social responsibility strategies are at a high level and are actively supported by the state and the business environment (Table 1). Among such countries there are Australia, Austria, Belgium, the United Kingdom, Greece, Denmark, Israel, Iceland, Spain, Italy, Canada, Cyprus, Luxembourg, Malta, the Netherlands, Germany, New Zealand, Norway, the United Arab Emirates, and South Korea. USA, France, Czech Republic, Switzerland, Sweden, Japan.

Table 1. Ranking of development of socially responsible companies by world regions

\begin{tabular}{|l|c|c|c|c|}
\hline \multicolumn{1}{|c|}{ Region } & $\begin{array}{c}\text { Amount of } \\
\text { states }\end{array}$ & $\begin{array}{c}\text { Amount of } \\
\text { companies }\end{array}$ & $\begin{array}{c}\text { Overall CSRHub } \\
\text { score }\end{array}$ & Rank \\
\hline Europe & 47 & 6904 & 55 & 1 \\
\hline South Asia & 5 & 2133 & 55 & 2 \\
\hline
\end{tabular}




\begin{tabular}{|l|c|c|c|c|}
\hline Africa & 28 & 940 & 54 & 3 \\
\hline Southeast Asia & 7 & 2521 & 53 & 4 \\
\hline South America & 10 & 924 & 50 & 5 \\
\hline Asia & 8 & 9627 & 50 & 6 \\
\hline Middle East & 16 & 1145 & 49 & 7 \\
\hline North America & 3 & 9506 & 48 & 8 \\
\hline Pacific states & 5 & 1679 & 48 & 9 \\
\hline Caribbean states & 14 & 644 & 47 & 10 \\
\hline
\end{tabular}

Such situation is determined by the fact that the instruments of corporate social responsibility can affect the level of competitiveness of corporations and the state as a whole.

The most responsible and active companies in terms of the concept of corporate social responsibility are often more effective. They attract consumers who are increasingly attentive to the conditions of production. In France, the Reputation Institute estimates that corporate social responsibility strategy accounts for almost $41 \%$ of consumers' perceptions of corporations and their reputations.

The Belgian government takes an active position and promotes the tools of corporate social responsibility. Belgium has adopted special legislation to regulate and promote the concept of corporate social responsibility. In addition, Belgium is considering approval of minimum standards and transparency criteria in line with international standards for socially responsible investment [3].

An example of the active role of the state in promoting the strategy of corporate social responsibility is the United Kingdom, which has achieved significant results in this area. Among the directions of the British corporate socially responsible policy there is support of innovative approaches and demonstrative practice of stakeholders and corporations; determining the minimum level of CSR, for example, on such fundamental issues as health, safety and equal opportunities; business support that brings social and environmental benefits to society [4].

Scandinavian corporations are often praised for their leadership in corporate social responsibility. These states also have the highest level of human development and a very high average per capita income. Business in Denmark, Sweden, Norway and Finland has long been the main strategy for corporate social responsibility. Many Scandinavian corporations rank first in the Dow Jones Index and the Global 100 Index. The Global Index rating shows that 2 Scandinavian states are in the top 10 states, the business of which is both competitive and sustainable (Denmark, Finland) [5].

Many industry companies are currently focused on business improvement initiatives and adopt different innovation programs in order to get long-term cost advantages or enhance operational flexibility [6]. Research published in recent years has demonstrated that corporations with good corporate social responsibility experience believe that their reputation and image are improving. The issue of developing a corporate social responsibility strategy is concerned by many companies around the world. The assessment of global companies based on the reputation of their corporate social responsibility is presented annually in the Global CR RepTrak 100 rating, which is conducted by the Institute of Reputation - an organization specialized in the study of brand reputation and corporate image. Data for this ranking were collected from the point of view of more than 
230 thousand people in 15 largest economies of the world and calculated on the basis of the following components of corporate social responsibility:

product - the availability of quality products that meet the needs of the consumer;

management practice - openness, transparency and ethics of doing business;

workplace practice - equal opportunities for employees and a fair system of motivation (remuneration) of the staff;

social responsibility - support of social and ecological principles of management;

leadership - the presence of courageous leaders with a clear mission and vision of how to achieve the goal [7].

To determine the role of tools of corporate social responsibility (social, economic, environmental) in the development of socio-economic position of the corporation and improve their reputation in the market, the following indicators were selected: Fortune Global 500 ratings, Net Promoter Score, Newsweek Green Ranking.

Fortune Global 500 is an annual ranking of 500 largest corporations around the world, the criteria for which is the total income. The ranking shows the largest corporate entities in the financial market, thus allowing to assess their economic development and market trends. All corporations are ranked according to the following indicators: total income, profit, assets, share capital, dynamics of income per share for the last 10 years, total annual income of all investors, average annual rate of total income of investors for the last 10 years. The ranking includes the US companies that submit an annual report to the US Securities and Exchange Commission on Form 10-K, as well as private companies which are registered outside the US and have open reporting [8].

The Net Promoter Score (NPS) is a measure of customer loyalty that measures a customer's willingness not only to return for another purchase or service, but also to give a recommendation to their family, friends or colleagues. This is a powerful and effective technique used by most corporations to increase revenue. NPS is measured from "-100" to "100". Management Policy Corporation with an NPS score above 0 is considered good, corporation management with an NPS score above 50 is considered excellent [9].

Green Ranking is one of the most recognized assessments of the environmental performance of the world's largest corporations in the financial market. Newsweek publishes the ranking of the world's largest companies in terms of corporate sustainability and environmental impact. 500 largest US companies and 500 largest global corporations are evaluated according to a methodology that takes into account eight key efficiency indicators: the ratio of energy and water use; greenhouse gas emissions and waste generation to the corporation's profits; the environmental impact of this income and the management mechanism that links the corporation's profits to environmental goals [10].

The professional rating of the largest mining and metals companies, based on the leading international practices, of corporate sustainability in Ukraine is represented in table 2 [11].

Let's consider the placement chart of mining and metals companies according to their ranks by the given indicators, in which the $\mathrm{x}$-axis includes the company's rank by indicator of Corporate sustainability and $y-y$ - the company's rank by indicator of Transparency (Figure). 
Table 2. Rating of the largest mining and metals companies by indicators of Corporate sustainability and Transparency

\begin{tabular}{|c|c|c|c|c|}
\hline 离 & 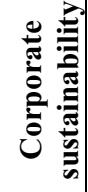 & 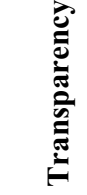 & 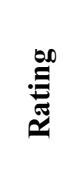 & 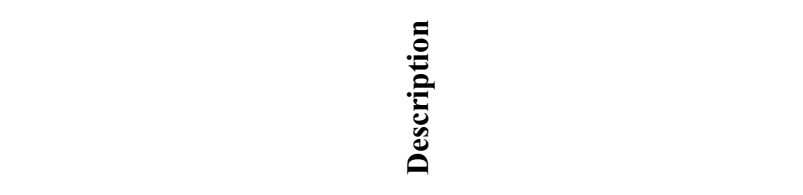 \\
\hline ArcelorMittal & $\mathrm{CC}$ & $\mathrm{CCC}$ & 4 & $\begin{array}{l}\text { World's largest metallurgical company. At the end of } 2008 \text {, it } \\
\text { controlled } 10 \% \text { of the world steel market. Registered in } \\
\text { Luxemburg, with offices in } 60 \text { countries. }\end{array}$ \\
\hline $\begin{array}{l}\text { Dneprovskiy } \\
\text { Metallurgical } \\
\text { Plant }\end{array}$ & D & $\mathrm{D}$ & 7 & $\begin{array}{l}\text { One of the largest enterprises in Ukrainian industry. The only } \\
\text { supplier of rolled axial pieces for rail transport, subway rails, } \\
\text { etc. }\end{array}$ \\
\hline DTEK & A & AA & 2 & $\begin{array}{l}\text { The largest privately owned and vertically integrated energy } \\
\text { company in Ukraine/ The Group's scope of operation includes } \\
\text { natural gas and coal production, renewable and thermal } \\
\text { generation of electricity, etc. }\end{array}$ \\
\hline INTERPIPE & $\mathrm{D}$ & $\mathrm{CC}$ & 6 & $\begin{array}{l}\text { INTERPIPE has a vertically integrated business structure, } \\
\text { which includes } 5 \text { high efficient mills. They are INTERPIPE } \\
\text { STEEL (steel production), INTERPIPE VTORMET (scrap } \\
\text { processing), INTERPIPE NTRP (seamless steel pipes and } \\
\text { railway wheel production), INTERPIPE NIKO TUBE } \\
\text { (seamless steel pipes production), INTERPIPE NMPP (ERW } \\
\text { steel pipes production) }\end{array}$ \\
\hline Metinvest & AA & AA & 1 & $\begin{array}{l}\text { Metinvest is an international, vertically integrated mining and } \\
\text { metals company. The Group comprises mining and } \\
\text { metallurgical assets in Ukraine, Europe and the US, } \\
\text { complemented by a global sales network. Metinvest manages } \\
\text { the complete production chain, from extracting iron ore and } \\
\text { coal to manufacturing semi-finished and finished steel } \\
\text { products. With assets close to key railway lines and ports, } \\
\text { Metinvest can supply raw materials and steel products } \\
\text { anywhere in the world. }\end{array}$ \\
\hline $\begin{array}{l}\text { Nicopol } \\
\text { Ferroalloy } \\
\text { Plant }\end{array}$ & $\mathrm{A}$ & $\mathrm{CCC}$ & 3 & $\begin{array}{l}\text { One of the largest enterprises in Ukraine's metallurgical } \\
\text { industry, the largest ferroalloy plant in Europe, and the second- } \\
\text { largest producer of manganese alloys in the world. } 75 \% \text { of its } \\
\text { products are exported. }\end{array}$ \\
\hline $\begin{array}{l}\text { FERREXPO } \\
\text { Poltava } \\
\text { Mining }\end{array}$ & $\mathrm{C}$ & $\mathrm{CC}$ & 5 & $\begin{array}{l}\text { A private joint stock company located in Horishni Plavni. } \\
\text { Ukraine's largest exporter of iron ore to Europe }\end{array}$ \\
\hline
\end{tabular}

As you can see, the most socially responsible model corresponds to the lowest value of the company's rank in terms of indicators of Corporate sustainability and Transparency, i.e. in the coordinate plane of the ranks of mining and metals companies - this is point (A, A). 


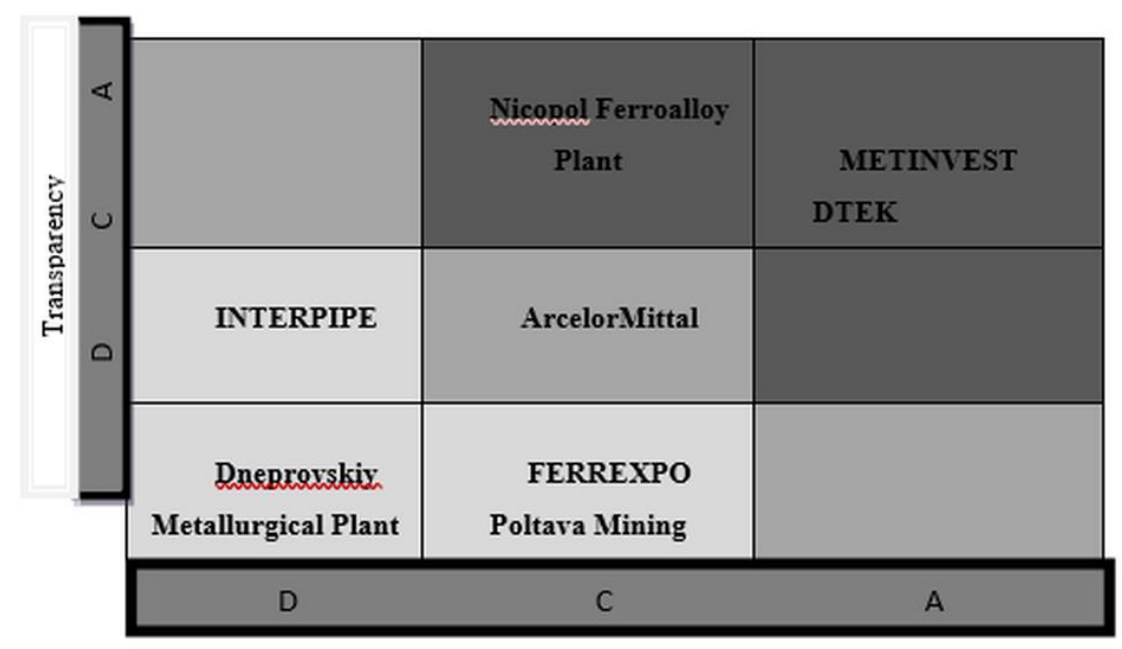

Fig. Location matrix of mining and metals companies with the highest reputation by indicators of Corporate Sustainability and Transparency in 2019

\section{Conclusion}

Based on the research conducted, it is determined that corporate social responsibility is an effective tool to increase competitiveness of mining and metals companies in the market. The corporate social responsibility policy is actively supported by all business entities. In the case of mining sustainable development impose the need to promote business models that ensure financially viable and environmentally sound projects, which take into account the aspects of corporate social responsibility $[12,13]$. The regions with the most common practices of implementing the concept of corporate social responsibility include North America (9 506 companies), Asia (9 627 companies), Europe (6 904 companies). The peculiarities of CSR practices in France, Belgium, Great Britain, and the Scandinavian states prove that corporations that have a strategy of corporate social responsibility are more efficient and competitive in the world market and have a high reputation.

The analysis of the international practice of development of CSR strategies allowed to allocate the projects which are the basis of directions and programs of corporate social responsibility of corporate business strategy: ecological projects; health, well-being and provision of basic social needs, social integration; financial management assistance; development of innovative products and services, more efficient use of resources; the link between CSR and business strategy.

Thus, mining companies need to join forces to take collective responsibility for the environment, social responsibility and corporate governance and ensure the necessary level of accountability and transparency by demonstrating that they are serious about this task. They should take on the development of a common international standard and define what constitutes responsible mining and how companies will report on adherence to such a standard. In line with this, mining companies should keep abreast of collaborative opportunities with external partners to share innovation risks, rethink their traditional business practices and strengthen relationships with local community stakeholders [14]. 
Building confidence in the mining industry is the responsibility of every mining company. The more companies are able to demonstrate that they are meeting the expectations of society, the more the industry will benefit from increased public acceptance and the ability to attract higher quality capital for a longer period.

\section{References}

1. T. Burmaka, N. Orlova,, O. Nepomnyashchyy, O Melnykovych, O. Medvedchuk, I Lahunova. Social investment as a tool of corporate social responsibility realization in Europe (35 ${ }^{\text {th }}$ IBIMA International Business Information Management Conference, Spain, 2020)

2. Browse CSR ratings by region and country. csrhub.com. Retrieved from https://www.csrhub.com/CSR_ratings_by_region_and_country/

3. CSR in the United Kingdom. sofidel.com. Retrieved from https://www.sofidel.com/en/sofidel-group/our-values

4. O.V. Bodnaruk, European experience of state regulation of corporate social responsibility Manager, 2:71 (2016)

5. Global 100 results. corporateknights.com. Retrieved from https://www.corporateknights.com/reports/2019-global-100/2019-global-100-results15481153/ (2019).

6. O. Garafonova, Y. Lazarenko, S. Grigashkina, I. Verezomska, E3S Web of Conferences, 174, 02001 (2020)

7. Corporate Responsibility RepTrak. reptrak.com. Retrieved from https://www.reptrak.com/csr-reptrak/

8. Global 500. fortune.com. Retrieved from https://fortune.com/global500/2019/search/?hqcountry=Japan.

9. NPS benchmarks. customer.guru. Retrieved from https://customer.guru/net-promoterscore/sony.

10. Best in industry global. newsweek.com. Retrieved from https://www.newsweek.com/best-in-industry-global-green-rankings-2017-18.

11. The professional rating, based on leading international practices, of corporate sutainability in Ukraine https://sustainableukraine.com/en/index.html\#block-8

12. O. Garafonova, E3S Web of Conferences, 41, 04006 (2018)

13. O. Garafonova, Y. Lazarenko, S. Grigashkina, I. Verezomska, E3S Web of Conferences, 134, 03011 (2019)

14. O. Garafonova, Y. Lazarenko, S. Grigashkina, I. Verezomska, E3S Web of Conferences, 105, 04042 (2019) 